\title{
PENGUATAN TATAKELOLA USAHA BAGI PENGRAJIN MINIATUR KAPAL KAYU DI DESA WRINGINREJO KABUPATEN MOJOKERTO
}

\author{
Sugeng Mulyono \\ Program Studi Manajemen, Fakultas Ekonomi dan Bisnis Universitas Gajayana, Jln. Mertojoyo \\ Blok L. Merjosari - Malang \\ E-mail: sugengmulyono@unigamalang.ac.id \\ Nyoman Susipta \\ Program Studi Manajemen, Fakultas Ekonomi dan Bisnis Universitas Gajayana, Jln.Mertojoyo \\ Blok L. Merjosari - Malang \\ E-mail: lancereltec@yahoo.com
}

\begin{abstract}
ABSTRAK
Kegiatan pengabdian kepada masyarakat ini dirancang guna mengoptimalkan kinerja pengrajin miniatur kapal kayu melalui peningkatan kemampuan dalam tatakelola keuangan, pemasaran dan modernisasi peralatan produksi. Sektor kerajinan ini mempunyai prospek usaha yang baik, mengingat tingkat persaingan rendah, pasar terbuka luas, efisien dalam proses produksi dan mampu menyerap tenaga kerja di Pedesaan. Efisiensi dapat dicapai karena sebagian material produksi memanfaatkan limbah pabrik. Metode pelaksanaan pengabdian ini menggunakan perpaduan pelatihan, pendampingan dan bantuan peralatan produksi. Pelatihan merupakan kegiatan penyampaian materi untuk meningkatkan pengetahuan dan ketrampilan bidang tatakelola keuangan dan pemasaran. Selanjutnya dilakukan pendampingan untuk mengimplementasikan materi pelatihan dan sekaligus monitoring perkembangan pengrajin. Selain itu, untuk meningkatkan kuantitas dan kualitas produksi, maka perlu diberikan bantuan peralatan produksi sebagai bagian dari upaya peningkatan kinerja bisnis. Kegiatan pengabdian ini telah berhasil meningkatkan pengetahuan dan ketrampilan pengrajin dalam tatakelola keuangan dan pemasaran, meningkatkan efisiensi proses produksi serta meningkatkan kuantitas dan kualitas produk.
\end{abstract}

Kata kunci: Tatakelola keuangan, Pemasaran, Kinerja.

\begin{abstract}
This community service activity is designed to optimize the performance of wooden boat miniature craftsmen through capacity building in financial management, marketing and modernization of production equipment. This handicraft sector has good business prospects, given the low level of competition, wide open market, efficient in the production process and able to absorb labor in the countryside. Efficiency can be achieved because some production material utilizes factory waste. The method of implementing this service uses a combination of training, assistance and production equipment assistance. Training is an activity to deliver material to improve knowledge and skills in the field of financial management and marketing. Further assistance was made to implement training materials and simultaneously monitor the development of craftsmen. In addition, to increase the quantity and quality of production, it is necessary to provide production equipment as part of efforts to improve business performance. This service activity has succeeded in increasing the knowledge and skills of craftsmen in financial and marketing governance, improving the efficiency of the production process and increasing the quantity and quality of products.
\end{abstract}

Keywords: Financial Governance, Marketing, Performance.

\section{PENDAHULUAN}

Pembangunan usaha mikro, kecil dan menengah (UMKM) dapat menggerakkan sektor riil, karena UMKM umumnya memiliki keterkaitan industri yang cukup tinggi. Karena keunikannya, maka pembangunan UMKM diyakini akan dapat memperkuat pondasi perekonomian nasional (LPPI dan BI, 2015). Apalagi dalam lima tahun terakhir, kontribusi sektor UMKM terhadap produk domestik bruto (PDB) semakin meningkat, yakni dari 57,84 persen menjadi 60,34 persen. Tak hanya itu, sektor UMKM juga telah membantu penyerapan tenaga kerja di dalam negeri. Serapan tenaga kerja pada sektor UMKM tumbuh dari 96,99 persen menjadi 97,22 persen dalam periode lima tahun terakhir. (Kompas, 28 Januari 2016). 
Peranan UMKM sebagai katub pengaman stagnasi ekonomi dan penopang PDB perlu dipertahankan bahkan ditingkatkan. Sektor ini sudah teruji ketangguhannya dalam menghadapi berbagai kejutan ekonomi dan berperanan penting sebagai penyedia lapangan kerja dalam skala besar. Untuk menjamin optimisme perkembangan UMKM dimasa depan memerlukan penataan dan penguatan kompetensi pengelolanya. Daya dukung permodalan, manajemen dan SDM yang berkualitas tinggi merupakan keharusan untuk optimalisasi kinerja UMKM secara berkelanjutan.

Namun demikian, sampai saat ini UMKM masih dihadapkan pada sejumlah kendala untuk peningkatan kinerjanya, antara lain: 1) sekitar 60-70\% UMKM belum mendapat akses atau pembiayaan perbankan; 2) manajemen bisnis UMKM masih dikelola secara manual dan tradisional, terutama manajemen keuangan dimana pengelola belum dapat memisahkan antara uang untuk operasional rumah tangga dan usaha; 3) kualitas sumber daya manusia (SDM) rendah; 4) kemampuan membaca kebutuhan pasar masih belum tajam, sehingga belum mampu menangkap dengan cermat kebutuhan yang diinginkan pasar; 5) pemasaran produk masih mengandalkan cara sederhana mouth to mouth marketing (pemasaran dari mulut ke mulut); 5) belum menjadikan media sosial atau jaringan internet sebagai alat pemasaran; dan 6) belum mempunyai badan hukum usaha (LPPI dan BI, 2015).

Dalam konteks ini, keberadaan pengrajin miniatur kapal kayu, sebagai bagian dari UMKM mempunyai peranan penting bagi penyediaan lapangan kerja di pedesaan. Apalagi sektor kerajinan ini telah berkembang cukup lama, yakni dimulai pada pertengahan tahun 1990. UMKM ini berada di Desa Wringirejo, Kecamatan Sooko Kabupaten Mojokerto dimana keberadaannya sangat bermanfaat bagi peningkatan pertumbuhan ekonomi desa serta dapat menyerap tenaga kerja pada Desa tersebut maupun di Desa sekitarnya.

Usaha kerajinan miniatur kapal kayu ini memproduksi jenis miniatur kapal kayu Phinisi dan Dewa Ruci sebagai produk utama. Khusus miniatur kapal Phinisi, oleh Pemkab Mojokerto diakui sebagai ikon daerah, karena mempunyai nilai historis sebagai kapal legendaris di jaman Kerajaan Mojopahit. Usaha kerajinan ini, mempekerjakan 9 orang karyawan bagian produksi yang diupah secara harian atau borongan.

Seiring dengan permintaan pasar, maka pengrajin terus melakukan inovasi antara lain memproduksi jenis miniatur kapal dalam botol atau bola lampu. Bahkan saat ini, produk hasil inovasi telah menjadi andalan bisnis. Tentu saja, harga kapal dalam botol atau bola lampu lebih mahal, karena tingkat kerumitan dalam proses pembuatan cukup tinggi. Dalam satu minggu rata-rata kapasitas produksinya sekitar 25 buah dengan mempekerjakan melibatkan 7-9 tenaga kerja.

Sebagai salah satu sektor usaha yang berperan penting dalam menggerakkan perekonomian desa, sektor usaha kerajinan perlu terus dikembangkan melalui peningkatan tatakelola bisnis utamanya bidang keuangan dan pemasaran dengan harapan agar kinerjanya menjadi lebih baik. Untuk itu perlu dilakukan peningkatan pengetahuan dan ketrampilan terhadap pengrajin tentang aspek keuangan dan pemasaran disertai dengan modernisasi peralatan produksi dengan harapan agar dapat meningkatkan efisiensi proses produksi serta meningkatkan kuantitas dan kualitas produksi.

\section{METODE PELAKSANAAN}

Metode pelaksanaan kegiatan ini terdiri dari beberapa tahap, yaitu: persiapan awal berupa survey pendahuluan guna menggali informasi sebagai dasar penyusunan materi pelatihan, metode pelatihan, pendampingan dan hibah peralatan produksi. Hal ini dimaksudkan agar pelaksanaan pelatihan dan pendampingan dapat tepat sasaran dan sesuai dengan kebutuhan pengrajin.

Selanjutnya, dilakukan pembekalan untuk penyusunan modul dan teknis pelatihan. Pelatihan dirancang dengan model partisipatif melalui penyajian materi yang disesuaikan dengan kebutuhan dan pengetahuan pengrajin. Adapun materi pelatihan yang disampaikan meliputi: akuntansi dasar, pemasaran, etika usaha dan penyusunan profil perusahaan.

Selanjutnya dilakukan pelatihan selama 3 hari dengan metode tutorial, diskusi dan praktek. Untuk mendukung efektivitas implementasi materi pelatihan maka peserta dibekali modul dengan disertai manual panduan praktek sehingga memudahkan untuk menerapkan secara mandiri.

Tahap berikutnya adalah penyerahan bantuan peralatan produksi. Pemberian bantuan peralatan produksi menyesuaikan dengan kebutuhan pengrajin. Bantuan peralatan ini diharapkan dapat meningkatkan kuantitas dan kualitas produk serta efisiensi dalam proses produksi.

Adapun tahap pendampingan merupakan tindak lanjut dari pelatihan tutorial. Rangkaian kegiatan pendampingan meliputi konsultasi, monitoring dan evaluasi. Tahapan ini dilakukan melalui kunjungan rutin kepada pengrajin setiap 3 minggu guna memantau perkembangan dalam mengimplementasikan materi pelatihan maupun perkembangan usaha. Teknis kegiatan pendampingan dapat dilaksanakan melalui pertemuan tatap muka 2 maupun kontak telepon/HP. Urutan langkah di atas tidaklah bersifat mutlak. Beberapa langkah dapat dilakukan secara simultan disesuaikan dengan perkembangan di lapangan.

\section{HASIL DAN PEMBAHASAN}

Pelaksanaan pengabdian kepada masyarakat bagi Pengrajin Kapal Kayu ini diharapkan dapat meningkatkan kinerja pengelola utamanya dalam tatakelola keuangan dan 
pemasaran guna meningkatkan kinerja bisnis. Untuk dapat membuahkan hasil yang diharapkan, memerlukan rangkaian kegiatan yang disusun secara sistematis baik metode pelatihan, materi yang disampaikan maupun metode pendampingannya. Ketiga rangkaian kegiatan tersebut perlu disesuaikan dengan kondisi obyektif yang selaras dengan kebutuhan pengrajin agar mudah dipahami dan diimplementasikan.

Pada tahap awal pelaksanaan pelatihan, instruktur menyampaikan tentang urgensi dan manfaat pelatihan bagi upaya memperbaiki tatakelola usaha. Penjelasan awal ini dipandang penting untuk membuka wawasan berpikir pengrajin yang selama ini terbiasa mengelola usaha dengan sistem tradisional. Pada tahap ini sudah nampak respons positif dari peserta berupa kesungguhan dalam mengikuti seluruh sesi pelatihan. Mereka menjadi pembelajar aktif yang antusias mengikuti proses pelatihan. Suasana pelatihan yang cukup kondusif ini, sangat membantu bagi instruktur untuk membangun komunikasi timbal balik dalam upaya memberikan penjelasan mendalam tentang materi yang diberikan.

Pelaksanaan pelatihan diikuti oleh 3 orang pengrajin. Sesuai dengan rancangan teknis pelaksanaan, maka metode pelatihan dalam bentuk ceramah dengan durasi waktu (a) 90 menit. Selanjutnya dilakukan tanya jawab maupun peragaan selama \pm 60 menit. Melalui metode ini diharapkan peserta pelatihan bisa memahami materi secara mendalam sehingga memudahkan mereka dalam penerapannya.

Materi pelatihan yang disampaikan oleh instruktur meliputi pengenalan akuntansi dasar, pemasaran, etika usaha dan penyusunan profile perusahaan. Materi ini diberikan agar tumbuh pemahaman bahwa dalam mengelola bisnis perlu perangkat keilmuan agar kinerja bisnis semakin meningkat.

Selama pelatihan berlangsung, peserta menunjukkan partisipasi aktif. Peserta pelatihan sangat antusias menanyakan tatacara pelaksanaan pembukuan yang benar, pemasaran yang baik dan metoda melayani konsumen yang dapat menumbuhkannya loyalitas pelanggan. Suasana pelatihan

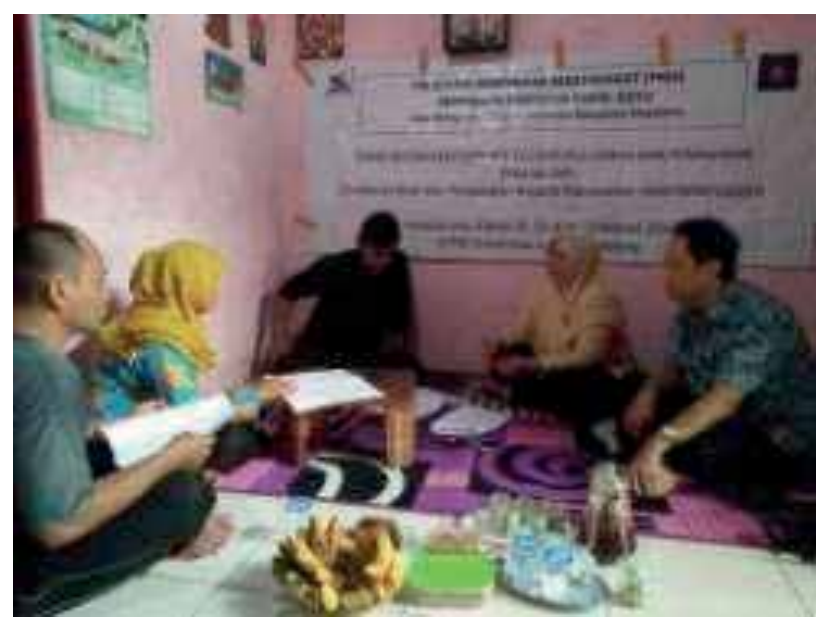

Gambar 1. Pelaksanaan Pelatihan terasa "hidup" karena instruktur dan peserta terlibat dalam diskusi intensif tentang materi pelatihan.

Peserta pelatihan merasa memperoleh pengetahuan dan ketrampilan baru untuk dimanfaatkan dalam meningkatkan pengelolaan usaha dan perluasan jaringan pemasaran produk.

Hasil dari pelatihan menunjukkan bahwa pengrajin mampu menerapkan pembukuan usaha, mereka sudah melakukan pencatatan dalam setiap transaksi, mencatat arus uang masuk maupun keluar. Pengetahuan dan ketrampilan ini dilaksanakan oleh pengrajin untuk memperbaiki pengelolaan keuangan yang selama ini belum dilakukan secara benar.

Selanjutnya materi tentang pemasaran. Materi ini diberikan guna memberikan perspektif kepada pengrajin bahwa kunci kemajuan usaha terletak pada seberapa besar pasar bersedia menerima barang yang ditawarkan oleh produsen. Selama ini pengrajin menggunakan metode pemasaran dari mulut ke mulut dan pameran. Setelah mendapat pelatihan, pengrajin menerapkan strategi pemasaran tambahan dengan menggunakan media internet maupun medsos.

Dari sudut pandang normatif, pelatihan seyogyanya dapat mengubah sistem berpikir dan perilaku individu peserta latihan, namun secara faktual bisa jadi berbeda. Perubahan sistem berpikir maupun perilaku individual peserta latihan terkadang bergerak agak lamban dan kurang sebangun dengan yang diharapkan. Peserta latihan lebih banyak bertumpu pada pengalaman praktis selama mengelola usaha, sementara instruktur terkadang terjebak pada teoritisnormatif. Sebab itu, komunikasi yang baik dengan pengrajin membantu efektivitas proses transformasi pengetahuan dan ketrampilan.

Selanjutnya dilakukan pemberian bantuan peralatan produksi untuk meningkatkan kuantitas dan kualitas produk. Peralatan produksi ini sangat diperlukan oleh pengrajin karena sangat membantu efisiensi dan peningkatan kapasitas produksi. Selama ini pengrajin menggunakan peralatan produksi yang sederhana sehingga berdampak pada kapasitas produksi yang terbatas dan produk yang dibuat kurang standar.

Untuk mengatasi kelambanan dalam proses produksi dan produk yang belum standar, maka dibutuhkan peralatan

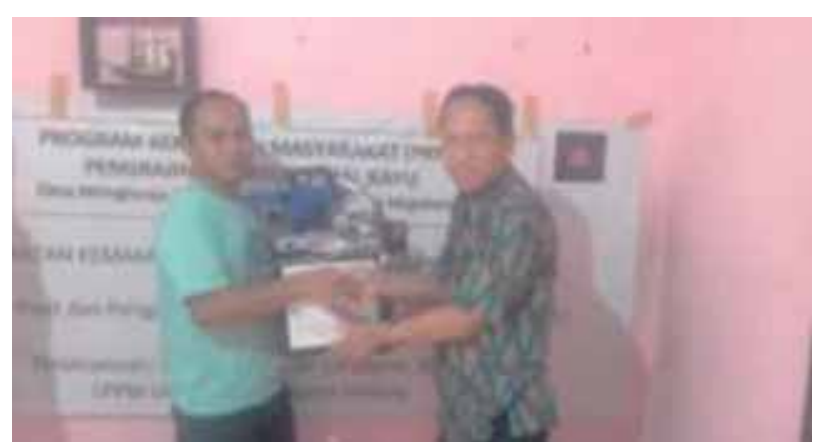

Gambar 2. Penyerahan Hibah Peralatan Produksi 
produksi. Sebab itu, maka hibah peralatan produksi bisa dimanfaatkan oleh mitra kerja untuk efisiensi proses produksi, meningkatkan kuantitas dan kualitas produk. Menurut pengrajin, salah satu kendala untuk meningkatkan kapasitas produksi adalah minimnya ketersediaan karyawan trampil dan peralatan produksi yang terbatas. Sehingga terkadang tidak berani menerima pesanan dalam skala besar. Manfaat bantuan peralatan produksi terbukti dapat meningkatkan efisiensi waktu dan biaya dalam mengerjakan produk kapal kayu. Sebagai gambaran, kalau semula untuk mengerjakan produk memerlukan waktu 2 hari dengan jumlah tenaga kerja 2 orang, maka dengan bantuan peralatan, maka pengerjaan produk hanya memerlukan waktu 1 hari dengan 1 orang tenaga kerja.

Selanjutnya dilakukan pendampingan. Pada tahap ini, dilaksanakan melalui 7 kali kunjungan ke lokasi pengrajin. Pendampingan dengan kunjungan ke lokasi pengrajin bertujuan agar dapat memantau secara langsung perkembangan kemampuan pengrajin dalam menerapkan materi pelatihan. Selama melakukan pendampingan, tim pelaksana memfokuskan pada pemanduan tatacara menerapkan materi yang belum dipahami utamanya bidang akuntansi. Materi ini memang memerlukan perhatian khusus. Sebab, peserta pelatihan masih belum dapat menerapkan secara optimal dikarenakan keterbatasan waktu untuk mempelajarinya.

Pada pendampingan pertengahan bulan Agustus 2018, menunjukkan bahwa sudah ada kemajuan pada pengrajin dalam menerapkan pembukuan usaha maupun cara memasarkan produk. Selain itu, bantuan peralatan produksi juga sudah dimanfaatkan secara optimal.

Dari rangkaian kegiatan pelatihan dan pendampingan terhadap pengrajin kapal kayu membuahkan hasil berupa peningkatan kemampuan dalam mengelola usahanya menjadi lebih baik dan efisiensi proses produksi sehingga bisnis yang telah ditekuni selama ini diharapkan dapat berkembang lebih maju.

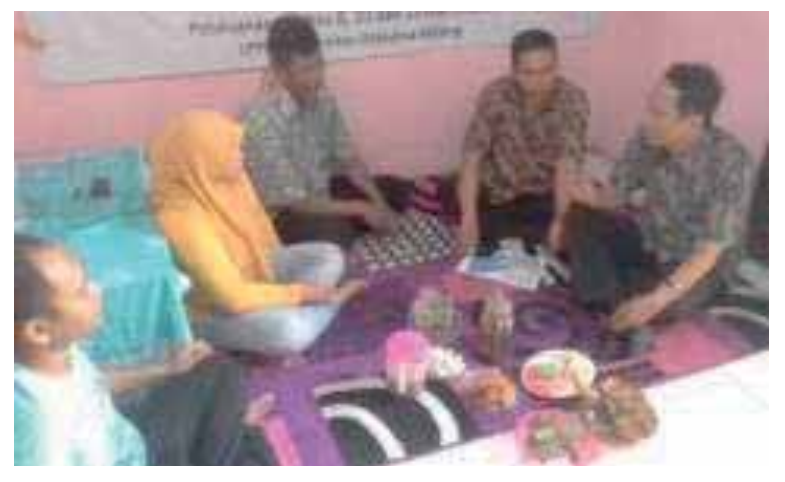

Gambar 3. Pendampingan

\section{PENUTUP}

\section{Kesimpulan}

Pelaksanaan kegiatan pengabdian kepada masyarakat bagi pengrajin kapal kayu di Desa Wringirejo Kabupaten Mojokerto mendapat respons positif dari peserta dalam wujud keterlibatan secara aktif selama pelaksanaan pelatihan dan bersedia mengikuti keseluruhan tahapan-tahapan pelatihan. Pada saat monitoring, evaluasi dan konsultasi menunjukkan bahwa pengrajin telah mengimplementasikan materi pelatihan.

Selanjutnya hibah peralatan produksi terbukti mampu mempercepat 2 kali lipat proses penyelesaian produk, dapat membuat produk lebih standar dan berkualitas baik. Sedangkan kemampuan pengrajin dalam bidang akuntansi dan pemasaran menunjukkan peningkatan yang signifikan, Dengan demikian, rangkaian pelaksanaan pelatihan dan pendampingan terhadap pengrajin ini terbukti berhasil meningkatkan kinerja usaha yang pada gilirannya dapat meningkatkan penghasilan mereka.

\section{Saran}

Untuk efektivitas pelaksanaan pengabdian kepada masyarakat, maka perlu pendekatan secara fleksibel, dalam artian metoda pelatihan dan pendampingan dikondisikan tidak terlalu formal serta ada kesediaan untuk menyesuaikan jadwal pelatihan maupun pendampingan dengan waktu luang mitra kerja.

Selain itu, perlu melakukan pendampingan secara intensif dan konsisten dalam kurun waktu lama agar mitra kerja dapat optimal menerapkan materi pelatihan serta mengetahui perkembangan kinerja usaha.

\section{UCAPAN TERIMA KASIH}

Kegiatan ini didanai oleh dana hibah Program Kemitraan Masyarakat (PKM) dari Kementrian Riset, Teknologi dan Perguruan Tinggi, Indonesia.

\section{DAFTAR PUSTAKA}

Kompas, 28 Januari 2016, diakses 20 Maret 2017 Lembaga Pengembangan Perbankan

Indonesia dan Bank Indonesia. 2015, Profil Bisnis Usaha Mikro, Kecil Dan Menengah (UMKM)

Meliala. A.S. Matondang.N. dan Sari. RM. 2014. Strategi Peningkatan Daya Saing Usaha Kecil Dan Menengah (UKM) Berbasis Kaizen. Jurnal Optimasi Sistem Industri, 13 (2):641- $664 \mathrm{x}$ 
Park, J.Y. dan Kim, S.W. 2010. An empirical model to assess the influence of the government's research and development program on Korean small and medium enterprise (SME) performance. The Asian Journal on Quality. 11 (3): 288-302.

Roosdhani.MR., Wibowo. PA dan Widiatuti.A. 2012. Analisis Tingkat Penggunaan Teknologi Informasi dan Komunikasi Pada Usaha Kecil Menengah Di Kabupaten Jepara, Jurnal Dinamika Ekonomi \& Bisnis. 8 (2): 89-104.

Sri Susilo, Y., 2007. Masalah dan Dinamika Usaha Kecil: Studi Empiris Pedagang "Klithikan" di Alun-alun Selatan. Jurnal Ekonomi, XII (01): 64 - 77.
Tambunan T dan Nasution.P. 2007. Pengkajian Peningkatan Daya Saing Usaha Kecil Menengah yang Berbasis Pengembangan Ekonomi Lokal. Jurnal Pengkajian Koperasi dan UKM. 2 (1).

Tambunan, TH. 2008. Usaha Kecil dan Menengah di Indonesia: Beberapa Isu Penting. Salemba Empat. Jakarta.

Undang-Undang Nomor 20. Tahun 2008 tentang Usaha Mikro Kecil dan Menengah. Penerbit Sinar Grafika, Jakarta. 